\title{
Life Cycle Assessment of maize cultivation for biogas production
}

\author{
J. Bacenetti, A. Fusi, R. Guidetti, M. Fiala \\ Department of Agricultural and Environmental Sciences. Production, Landscape, Agroenergy, \\ Università degli Studi di Milano, Milano, Italy
}

\section{Introduction}

The renewable sources for energy production is considered to be a potential solution for reducing the environmental problems derived from the fossil fuels use (Gonzalez-Garcia et al. 2012a). Besides the reduction of their consumption, during the past few decades more and more interest has been focused on the production of renewable energy.

In Europe, the interest for Renewable Energy Sources (RES) has strongly increased due to the need to reduce also the greenhouse gas (GHG) emissions, as RED (European Parliament, 2009) indicates.

Energy crops and the derived bioenergy production are expected to bring environmental, social and economic benefits. Several studies have reported benefits in terms of the reduction of $\mathrm{GHG}$, air pollution, acidification or eutrophication (Buratti and Fantozzi 2010; Bacenetti and Fiala 2011; Bacenetti et al. 2012a; González-García et al. 2012b).

However, the environmental impacts concerning bioenergy strongly depend on crops cultivation (Fazio and Monti 2011; Uchida and Hayashi 2012). Among the several possible solutions, the Anaerobic Digestion (AD)represents one of the most promising ways to use RES (Angelidaki and Ellegaard 2003; Jury et al. 2010; Patterson et al. 2011; Capponi et al. 2012).

The agricultural byproducts, such as animal slurry and manure, are commonly used for biogas production; nevertheless, the main biomass for digesters feeding are often represented by cereal silages (maize, wheat and triticale, in particular).

In Italy, about 1000 agricultural biogas plants are currently in function (380 located in Lombardy), for a global electrical power of $156 \mathrm{MW}$. Although no detailed information concerning the amount of silages

Correspondence: M. Fiala, Department of Agricultural and Environmental Sciences. Production, Landscape, Agroenergy, UniversitydegliStudi di Milano, via G. Celoria 2, 20133, Milano, Italy

E-mail:marco.fiala@unimi.it

Key words: biogas production, bioenergy, maize cultivation.

Acknowledgments: the present work is funded by RegioneLombardia - Fondo per la Promozione di AccordiIstituzionali, project BIOGESTECA 15083/RCC". The Authors thank also the RegioneLombardia which financed a Postdoctoral Research Fellowship ("Progetto Dote Ricerca" financed by FSE - RegioneLombardia).

Copyright J. Bacenetti et al., 2013

Licensee PAGEPress, Italy

Journal of Agricultural Engineering 2013;XLIV(s2):e114

doi:10.4081/jae.2013.s2.e114

This article is distributed under the terms of the Creative Commons Attribution Noncommercial License (by-nc 3.0) which permits any noncommercial use, distribution, and reproduction in any medium, provided the original author(s) and source are credited. used to feed the $\mathrm{AD}$ plants is available, the areas in which biogas production is more widespread along with an increase in biomass prices and the value of lands has taken place (Povellato, 2011).

The environmental effects due to energy crop cultivation come not only from field operations but also from the inputs (fuels, fertilizers and pesticides) extraction, production and transportation. Therefore, in order to perform a complete evaluation of the system, all of these aspects must be taken into account.

The aim of this study is to analyze the environmental performances of maize silage for biogas production

\section{Introduction}

\section{Goal and scope definition}

The environmental performances of maize FA0 class 700 (maize 700 ) cultivation were assessed in terms of methane potential production. Maize is commonly used as animal feed, but nowadays -in Northern Italy- it plays an important role for biogas production, too.

This analysis was performed using the Life Cycle Assessment (LCA) methodology able to analyze products, processes or services from an environmental perspective (Guinée et al. 2002; ISO 2006).

\section{Description of the crop cultivation}

The cultivation under assessment is carried out in the Po Valley area, district of Milan, Lombardy Region (Italy). The local climate is characterized by an average annual temperature of $12.7^{\circ} \mathrm{C}$ and the rainfall is mainly concentred in Autumn and Spring (average annual precipitation is equal to $745 \mathrm{~mm}$ ).

Field and ensilage operations are reported in Table 1 and shown in Figure 1. Field operations can be divided into: (1) soil tillage, (2) crop management (cover fertilization, weed and pest control), (3) biomass harvesting and transport and (4) biomass ensilage.

The crop cultivation starts on May with organic fertilization and ends on September when maize is harvested and immediately ensiled. The biomass yield is 75 twb-ha-1(dry matter content of $34.9 \%)$.

\section{Functional unit and system boundaries}

Considering that the analysis was performed on the crops that were specifically cultivated for energy generation by means of AD plants, the selected functional unit was 1 tonne of fresh silage (1tWB).

The system boundaries (Figure 1) included crop cultivation and harvesting, biomass transport and ensilage to the close biogas plant.

\section{Life cycle inventory}

Data (year 2011) concerning the field operations, ensilage and transport were directly obtained by means of questionnaires (administered to farmers) as well surveys and tests on the field.

Information regarding seeds, fertilizers, pesticides and water use were provided by the farmer as well as the diesel fuel consumption. Emissions due to the fertilizers includenitrogen emissions (nitrate, 
ammonia, and nitrous oxide) computed in according to Brentrup et al. (2000). Phosphate emissions were calculated following Smil (2000). Climatic data for year 2011, which were necessary for calculating the fertilizer emissions, were obtained from the meteorological station closest to the farm. Pesticide emissions were also estimated using PestLCI (Birkved and Hauschild 2006).

The emissions due to diesel fuel use were estimated using the Swiss Federal Office for the Environment Database (Federal

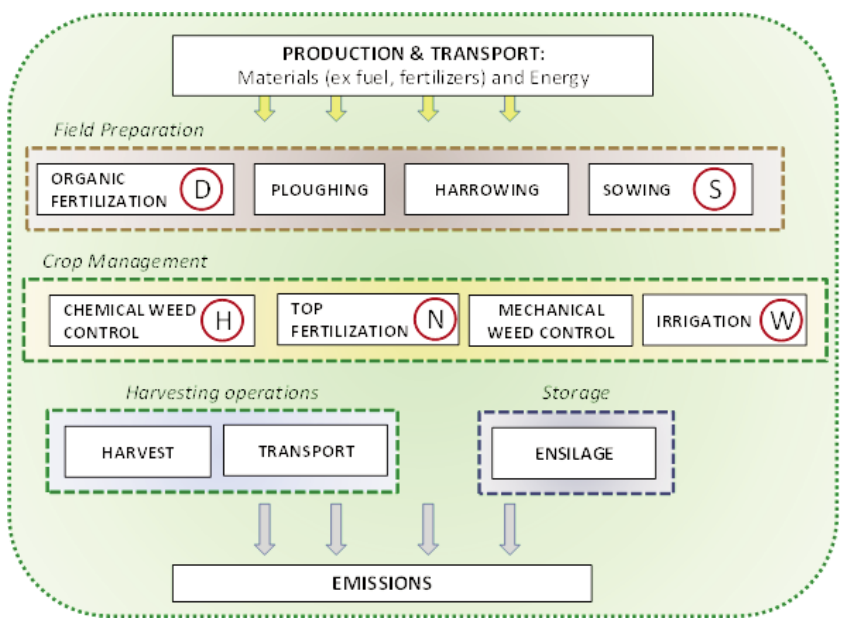

Figure 1. System boundaries

Note: $\mathrm{D}=$ digestate, $\mathrm{S}=$ seeds, $\mathrm{H}=$ herbicide, $\mathrm{N}=$ nitrogen fertilizer, $\mathrm{W}=$ water

Department of the Environment, Transport, Energy and Communications, or DETEC); secondary data for seed production, diesel fuel, fertilizers and pesticides were obtained from the Ecoinvent database and the LCA Food DK database (Nielsen et al. 2003).

Considering that the soil was previously dedicated to maize cultivation,zero change in the overall soil carbon content has been assumed.

\section{Methods}

A life cycle impact assessment (LCIA) was performed using SimaPro software (PRé Consultants - http://www.pre-sustainability.com/simapro -lca-software) and CML 2000 (Guinée et al. 2002) was chosen as a method with which to assess the environmental impact.

Table 2. Scores for all impact categories for the FU

\begin{tabular}{lcc}
\hline IMPACT CAVEGORIES & UNIIS & TOTAL \\
\hline Abioticdepletion & $\mathrm{kg} \mathrm{Sb}$ eq & 0,104624 \\
Acidification & $\mathrm{kg} \mathrm{SO} \mathrm{eq}_{2}$ & 1,378419 \\
\hline Eutrophication & $\mathrm{kg} \mathrm{PO} \mathrm{eq}$ & 0,412833 \\
Global warming (GWP100) & $\mathrm{kg} \mathrm{CO}_{2} \mathrm{eq}$ & 29,75866 \\
\hline Ozonelayerdepletion (ODP) & $\mathrm{kg} \mathrm{CFC}-11 \mathrm{eq}$ & $2,11 \mathrm{E}-06$ \\
Human toxicity & $\mathrm{kg} \mathrm{1,4-DB} \mathrm{eq}$ & 3,445905 \\
\hline Fresh water aquaticecotoxicity & $\mathrm{kg} \mathrm{1,4-DB} \mathrm{eq}$ & 0,830076 \\
Marine aquaticecotoxicity & $\mathrm{kg} \mathrm{1,4-DB} \mathrm{eq}$ & 2305,503 \\
\hline Terrestrialecotoxicity & $\mathrm{kg} \mathrm{1,4-DB} \mathrm{eq}$ & 0,023476 \\
Photochemicaloxidation & $\mathrm{kg} \mathrm{C} \mathrm{H}_{4} \mathrm{eq}$ & 0,003256 \\
\hline
\end{tabular}

\begin{tabular}{|c|c|c|}
\hline $\begin{array}{ll}\text { 口Pre-seeding organic fertilization } & \text { aPloughing } \\
\text { 口Chemical Weeding } & \text { वTop fertilization } \\
\text { a Harvesting } & \text { वTrasport }\end{array}$ & $\begin{array}{l}\text { घharrowing } \\
\square \text { Mechanical Weeding } \\
\square \text { Ensilage }\end{array}$ & $\begin{array}{l}\text { 口Sowing } \\
\text { |rigation }\end{array}$ \\
\hline
\end{tabular}

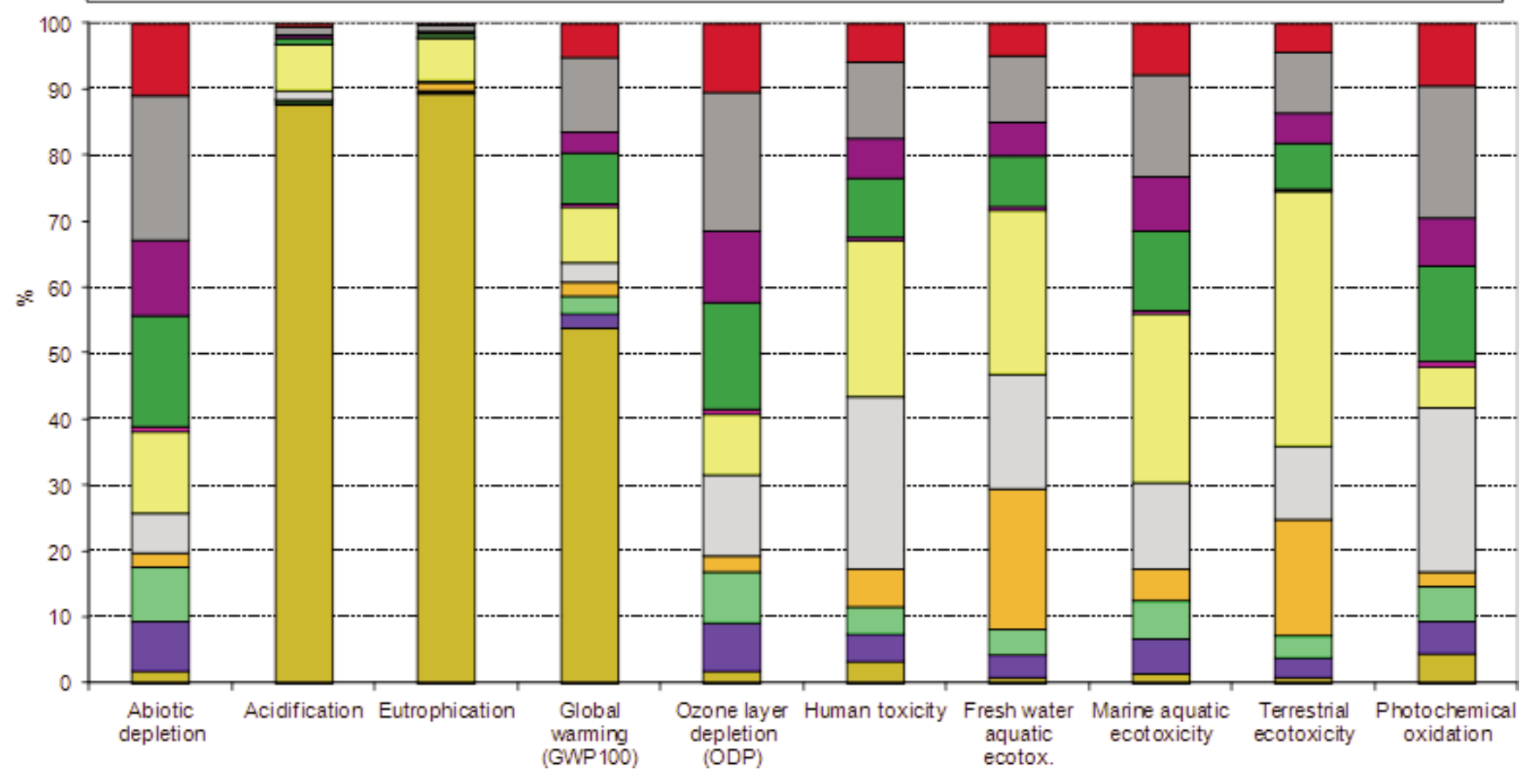

Figure 2. Impact of operations on the different impact categories 


\section{Results and discussion}

The environmental impact is widely influenced, as expected, by the field operations; on the contrary, less than $5 \%$ of the overall environmental impact is due to the ensilage activity. Consequently, the operations carried out on the field are the main responsible (more than 95\%) of the environmental burdens for all the 10 impact categories.

Among the different inputs and output s, the key aspects are: (i) fertilizer emissions (mainly for acidification and eutrophication impact categories), (ii) diesel fuel emissions (mainly for global warming potential impact category), (iii) diesel fuel production (mainly for abiotic depletion and ozone layer depletionimpact categories) and(iv) pesticides production (important for human toxicityimpact category).

Regarding the different field operations, the influence over the 10 impact categories is quite variable (Figure 2); for example, the fertilization is responsible for about 95\% of acidification and eutrophication but less than $35 \%$ for the others impact categories.

\section{Conclusions}

The study assesses the environmental performances of maize FAO class 700; this cereal is the most widespread in Italy and it islargely utilized for biogas production.

The study points out that the environmental burdens of maize 700 cultivation are mainly due to: (i) crop fertilization (in particular nitrogen application, primarily via organic fertilizers) and (ii) mechanization of field operations.

The analysis highlighted that the nitrogen cycle and the linked emissions are relevant for the environmental burden of crop cultivation, especially foracidification and eutrophication. Organic fertilization, carried out with a high-rate of digestate, involves high emissions in atmosphere of ammonia and nitrogen dioxide, especially when the spreading is performed distributing the digestate directly on the soil surface and without a fast burial.The digestateinjection into the soil largely reducesthe ammonia emissions.

Mechanization requiresa high diesel fuel consumption and, consequently, a significant impact on GWP and abiotic depletion as well.
Reduction of the diesel fuel consumption, thatcould significantly improve the environmental performances, can be achievedthrough:

1. the introduction of proper technical solutions connected with lower mechanical power requirements (i.e. minimum tillage, sod seeding, slattedmouldboards).

The obtained results represent the environmental evaluation onlyof the first step of the whole biogas process. Future analysis will take into consideration the biogas production (microbiological digestion) and its final conversion into energy by a cogenerated i.c. engine (CHP).

\section{References}

1. Angelidaki I., Ellegaard L.,Codigestion of manure and organic wastes in centralized biogas plants: status and future trends. Applied Biochemistry Biotechnology 2003; 109: 95-105.

2. Audsley E.,Harmonisation of environmental life cycle assessment for agriculture. Final Report, Concerted Action AIR3-CT94-2028. European Commission, DG VI Agriculture, 1997, 139 pp.

3. Bacenetti J., Mena A., Negri M., Cantarella P., Bocchi S., Fiala M., Energetic and Environmental Balance of a Biogas Plant in Northern Italy. Proceedings CIGR-AgEng 2012 International Conference on Agricultural Engineering Valencia: CIGR-AgEng, 2012.

4. Bachmaier J., Effenberger M., Gronauer A. Greenhouse gas balance and resource demand of biogas plants in agriculture, Engineering in Life Sciences, 2010; 10: 560-569.

5. Birkved M.,Hauschild M. PestLCI-A model for estimating field emissions of pesticides in agricultural LCA. Ecological Modelling 2006; 198: 433-451.

6. Brentrup F., Küsters J, Lammel J, Kuhlmann H., Methods to estimate on-field nitrogen emissions from crop production as an Input to LCA studies in the Agricultural Sector. Int J Life Cycle Ass 2000;5:349-57.

7. Buratti C., Fantozzi F., Life cycle assessment of biomass production: Development of a methodology to improve the environmental indicators and testing with fiber sorghum energy crop. 2010; 34: 1513-1522.

8. Capponi S., Fazio S., Barbanti L., C02 savings affect the break-even distance of feedstock supply and digestate placement in biogas pro-

Table 1. Field and ensilage operations for single crop (maize 700)

\begin{tabular}{|c|c|c|c|c|c|c|c|}
\hline \multirow[t]{2}{*}{ OPERATION } & \multirow[t]{2}{*}{ NN. } & \multirow[t]{2}{*}{ MONIH } & \multirow{2}{*}{$\begin{array}{c}\text { TRACTOR } \\
\text { Mass (kg) Power (kW) }\end{array}$} & \multicolumn{3}{|c|}{ OPERATIVE MACHINE } & \multirow[t]{2}{*}{ NOTE } \\
\hline & & & & Type Size & Mass (kg) & Time (h/ha) & \\
\hline Organic fertilization & 1 & May & $5050(90)$ & Manure spreader $20 \mathrm{~m}^{3}$ & 2000 & 3.33 & $\begin{array}{c}85 \mathrm{t} \cdot \mathrm{ha} \mathrm{a}^{-1} \\
\text { Digestate }^{[\mathrm{a}]}\end{array}$ \\
\hline Ploughing & 1 & May & $10500(190)$ & Plough & 2000 & 1.11 & - \\
\hline Harrowing & 1 & May & $7300(130)$ & Rotary Harrow 4,0 m & 1800 & 1.20 & - \\
\hline Sowing & 1 & May & $5050(90)$ & Pneumatic seeder 4 rows & 900 & 1.00 & $20 \mathrm{~kg} \cdot \mathrm{ha}^{-1}$ \\
\hline \multirow[t]{3}{*}{ Chemical Weeding } & 3 & May Jun Jun & $4450(80)$ & Sprayer $15 \mathrm{~m}$ & 600 & 0.33 & $4 \mathrm{~kg}$-ha-llumax \\
\hline & & & & & & & $1 \mathrm{~kg} \cdot h a^{-1}$ dual \\
\hline & & & & & & & $1 \mathrm{~kg} \cdot \mathrm{ha}^{-1}$ dual \\
\hline Irrigation & 5 & Jun Jul Aug & $4450(80)$ & Pump $950 \mathrm{~m}^{3} / \mathrm{h}$ & 550 & 1.20 & $4400 \mathrm{~m} 3 \cdot \mathrm{ha}^{-1}$ \\
\hline Mechanical Weeding & 1 & Jun & $5050(90)$ & Weeder $2,8 \mathrm{~m}$ & 550 & 0.33 & - \\
\hline Top fertilization & 1 & Jun & $6850(120)$ & Fertilizer spreader $2500 \mathrm{dm}^{3}$ & 500 & 0.13 & $60 \mathrm{~kg} \cdot \mathrm{ha}^{-1}$ Urea \\
\hline Harvesting & 1 & Sep & - & Forage harvester & $335 \mathrm{~kW}$ & 13000 & 1.00 \\
\hline
\end{tabular}


duction. Renewable Energy 2012, 37: 45-52.

9. Casati D., 2011. Le superfici possono ricominciare a salire. Terra e Vita, 35, 40-46.

10. DETEC (Federal Department of the Environment, Transport, Energy and Communications), http://www.bafu.admin.ch/index. html?lang=it last visit 05/02/2013

11. Dressler D., Loewen A., Nelles M., Life cycle assessment of the supply and use of bioenergy: impact of regional factors on biogas production. The International Journal of Life Cycle Assessment 2012; 17 (9):1104-1115.

12. European parliament and council. Directive 2009/28/EC on the promotion of the use of energy from renewable sources. In: Official Journal of the EuropeanCommunities, Vol. L 283/33; 2009.

13. Fazio S., Monti A., Life cycle assessment of different bioenergy production systems including perennial and annual crops, Biomass Bioenerg. 2011, 35, pp. 4868 - 4878.

14. Fiala M., Bacenetti J., Model for the economic, energetic and environmental evaluation in biomass productions. Journal of Agricultural Engineering 2012; 42: 26-35.

15. Goedkoop M, de Schryver A and Oele M., Introduction to LCA with SimaPro 7. PRé Consultants, the Netherlands; 2008.

16. González-García S., Bacenetti J., Murphy R.J., Fiala M., Present and future environmental impact of poplar cultivation in Po Valley (Italy) under different crop management systems. Journal of Cleaner Production. 2012; 26:56-66.

17. González-García S., Bacenetti J., Negri M., Fiala M., Arroja L. Comparative environmental performance of three different annual energy crops for biogas production in Northen Italy. Journal of Cleaner Production 2012; doi:10.1016/j.jclepro.2012.12.017.

18. Guinée J.B. (Ed.), Handbook on Life Cycle Assessment, Operational Guide to the ISO Standards, 2002, 1-708.

19. IPCC, Agriculture, Forestry and Other Land Use. In: Eggleston et al.,
IPCC Guidelines for National Greenhouse Gas Inventories, Prepared by the National Greenhouse Gas Inventories Programme, 2006.

20. ISO, Environmental management-Life cycle assessment-Principles and framework (ISO 14040), 2006 Brussels: European Committee for Standardization.

21. ISTAT - Istituto Nazionale di Statistica, Tavola C02 - Superficie (ettari) e produzione (quintali): riso, mais, sorgo, altri cereali. Dettaglio per regione - Anno 2011, (http://agri.istat.it/jsp/ dwExcel.jsp?q=plC020000010000012000\&an=2011\&ig=1\&ct=244 \&id=18Al15Al25A last access 21/12/12)

22. Jury C., Benetto E., Koster D., Schmitt B., Welfring J., Life Cycle Assessment of biogas production by monofermentation of energy crops and injection into the natural gas grid. Biomass Bioenerg 2010; 34: 54-66.

23. Lansche J., Müller J., Life cycle assessment of energy generation of biogas fed combined heat and power plants: Environmental impact of different agricultural substrates. Engineering in Life Sciences 2012; 12: 313-320.

24. Nielsen PH, Nielsen AM, Weidema BP, Dalgaard R and Halberg N (2003). LCA food data base. www.lcafood.dk

25. Patterson T., Esteves S., Dinsdale R., Guwy A., Life cycle assessment of biogas infrastructure options on a regional scale. Bioresource Technology 2011; 15: 7313-7323.

26. Povellato A., Aumenta la superficie in affitto delle aziende professionali. L'Informatore Agrario 2011; 40: 32-39.

27. Smil V., Phosphorus in the environment: Natural Flows and Human Interferences 2000 Annu. Rev. Energy Environ. 2000. 25:53-88)

28. Uchida S., Hayashi K., Comparative life cycle assessment of improved and conventional cultivation practices for energy crops in Japan. Biomass Bioenerg 2012;36:302-15. 